\title{
Purification, and biochemical and structural characterization of a fimbrial haemagglutinin of Renibacterium salmoninarum
}

\author{
J. Daniel Dubreuil, ${ }^{1 *}$ Mario Jacques, ${ }^{1}$ Lori Graham ${ }^{2}$ and Real Lallier ${ }^{1}$ \\ ${ }^{1}$ Department of Pathology and Microbiology, Faculty of Veterinary Medicine, University of Montréal, PO Box 5000, \\ Saint-Hyacinthe, Québec, Canada J2S 7C6 \\ ${ }^{2}$ Department of Microbiology, College of Biological Science, University of Guelph, Guelph, Ontario, Canada NIG 2WI
}

(Received 11 May 1990; accepted 6 August 1990)

\begin{abstract}
Renibacterium salmoninarum was shown to possess peritrichous fimbriae. Electron microscopy of strains FMV 84-01 and ATCC $33209^{\mathrm{T}}$ revealed short, flexible fimbriae less than $2 \mathrm{~nm}$ in diameter. These surface appendages were isolated from the bacteria by a procedure involving water extraction and urea solubilization. The fimbrin was purified to homogeneity by Fast Pressure Liquid Chromatography, and shown by SDS-PAGE to be a protein of $57 \mathrm{kDa}$. Isoelectric focusing under non-denaturing conditions indicated a pI of 4.8. The protein had an amino acid composition rich in glycine, Asx (aspartic acid and asparagine), valine and alanine; methionine was absent. Approximately $33 \%$ of the amino acid residues were hydrophobic. Immunoblotting using a polyclonal antiserum raised against whole cells showed that the $57 \mathrm{kDa}$ protein was the immunodominant antigen on the cell surface. Immunogold labelling using polyclonal antibodies raised against the fimbrin revealed an alignment of gold particles along the fimbriae. Purified fimbriae caused agglutination of rabbit erythrocytes and antifimbrial serum inhibited this haemagglutination. Altogether the results indicate that the fimbriae on the surface of $R$. salmoninarum are responsible for the haemagglutinating activity.
\end{abstract}

\section{Introduction}

Renibacterium salmoninarum is the aetiological agent of bacterial kidney disease and is responsible for significant mortality in salmonid fish throughout the world (Fryer \& Sanders, 1981). R. salmoninarum represents a unique bacterial pathogen in that the isolates obtained from several sources around the world show uniformity in biochemical properties (Bruno \& Munro, 1986) and antigenicity (Bullock et al., 1974). Getchell et al. (1985) claimed that the isolates shared seven antigens. Two cell wall components have been found to be characteristic of the type strain (ATCC $33209^{\mathrm{T}}$ ): a unique peptidoglycan and an unusual cell wall polysaccharide having galactose, rhamnose, $N$-acetylglucosamine and $N$-acetylfucosamine as constituents (Kusser \& Fiedler, 1983). More recently, a study of the biochemical composition of the cell envelope indicated a marked similarity in the peptidoglycan and polysaccharides of various isolates and the type strain (Fiedler \& Draxl, 1986). Interestingly, the polysaccharide amounted to more than $60 \%$ of the dry weight of the cell walls. The authors concluded that the surface of the cell is formed mainly by this unique polysaccharide. Their study also revealed that antigenic proteins were attached to the cell wall. We have recently shown that $R$. salmoninarum is encapsulated (Dubreuil et al., 1990), which might explain the presence of an unusual amount of polysaccharide in the cell wall preparation.

Daly \& Stevenson (1987), studying 25 isolates from diverse geographical locations, showed that $R$. salmoninarum possessed a hydrophobic cell surface. The hydrophobicity was shown to be due to the presence of a proteinaceous haemagglutinin/spermagglutinin (Daly \& Stevenson, 1989, 1990). This protein could be removed from the cell surface by washing the bacteria with distilled water and had a molecular mass of $57 \mathrm{kDa}$. Recently, Bruno (1990) showed saline extracts of virulent strains to contain a $57 \mathrm{kDa}$ protein which was not present in extracts of low-virulence strains. The study related the hydrophobic nature and the autoaggregating property of virulent isolates with the presence of this saline-extractable protein.

Haemagglutinating activity has been reported for $R$. salmoninarum for rabbit, pigeon, horse and rat erythrocytes (Daly \& Stevenson, 1987). This activity was resistant to mannose, D- and L-fucose, galactose and $N$-acetylglucosamine. Up to now, no surface appendages 
such as fimbriae have been revealed by transmission electron microscopy. However, it has been noticed that $R$. salmoninarum forms a pellicle in broth and has a tendency to autoaggregate, two properties often related to the presence of fimbriae (Smith, 1964; Daly \& Stevenson, 1987; Bruno, 1988).

This study is the first to show that $R$. salmoninarum isolates possess fimbriae. These proteinaceous structures were isolated and the fimbrin subunits purified and biochemically characterized.

\section{Methods}

Bacterial strains and growth medium. Renibacterium salmoninarum strain FMV 84-01 was isolated from the kidney of a diseased speckled trout, Salvelinus fontinalis. Many vials of the strain were freeze-dried immediately after isolation and identification. Bacteria were grown on charcoal agar plates (Daly \& Stevenson, 1985 ) at $16^{\circ} \mathrm{C}$ for $12-15 \mathrm{~d}$. The type strain ATCC $33209^{\mathrm{T}}$ was also used for electron microscopical characterization of the cell surface.

Extraction and purification of fimbrial protein. Cultures (12-15 d old) of $R$. salmoninarum FMV 84-01 were harvested and suspended in sterile distilled water ( $3 \mathrm{~g}$ in $100 \mathrm{ml}$ ) containing $5 \mathrm{~mm}$-phenylmethylsulphonyl fluoride (PMSF, Boehringer Mannheim) as a protease inhibitor. The suspension was stirred vigorously for $20 \mathrm{~min}$ at room temperature. Whole cells were then removed by centrifugation at $12000 \mathrm{~g}$ for $15 \mathrm{~min}$. The supernatant was filter-sterilized $(0.22 \mu \mathrm{m}$ pore-size filter, Millipore) and the solution was then lyophilized. The sample was rehydrated in one-twentieth the initial volume of potassium phosphate buffer $(0.02 \mathrm{M} ; \mathrm{pH} 7.4)$. Since the protein of interest was insoluble in this buffer, the concentrated sample was centrifuged at $12000 \mathrm{~g}$ for $15 \mathrm{~min}$. The precipitate was then solubilized in phosphate buffer containing $6 \mathrm{M}$-urea (BDH) and centrifuged again for $15 \mathrm{~min}$ at $12000 \mathrm{~g}$. The supernatant was purified to apparent homogeneity using a Fast Pressure Liquid Chromatography (FPLC) system (Pharmacia) coupled to a Superose 12 column equilibrated in the same buffer. The system was run at a flow rate of $0.5 \mathrm{ml} \mathrm{min}{ }^{-1}$. The $A_{280}$ of the effluent was monitored with a UV-M detector.

Antibody production. Antiserum was raised in two adult New Zealand White rabbits by intramuscular injections. One rabbit was immunized with a formalin-killed bacterial suspension of $10^{9}$ cells $\mathrm{ml}^{-1}$ of a 15-d-old culture of $R$. salmoninarum FMV 84-01: $1 \mathrm{ml}$ of this suspension was emulsified with an equal volume of Freund's complete adjuvant. The other rabbit was injected with $50 \mu \mathrm{g}$ of FPLC-purified protein in Freund's complete adjuvant. A booster dose was given in Freund's incomplete adjuvant to each rabbit on days 14 and 28 . On day 42 the rabbits were exsanguinated and the serum collected and stored at $-20^{\circ} \mathrm{C}$. Control non-immune serum was obtained before the first injection.

Electrophoresis. SDS-PAGE was performed by the method of Laemmli (1970) in a mini-slab gel apparatus (Hoefer). Proteins solubilized in sample buffer were stacked in $4.5 \%(\mathrm{w} / \mathrm{v})$ acrylamide ( $100 \mathrm{~V}$; constant voltage) and separated by using $12.5 \%$ acrylamide ( $200 \mathrm{~V}$; constant voltage). Proteins were stained with Coomassie blue, and glycoconjugate compounds were stained by the periodate-Schiff procedure (Fairbanks et al., 1971).

For electroblotting, separated proteins were transferred from the slab gel to nitrocellulose paper by the methanol/Tris/glycine system described by Towbin $e$ t al. (1979). Electroblotting was performed in a Hoefer Transblot apparatus for $18 \mathrm{~h}$ at $60 \mathrm{~V}$. Non-denaturing isoelectrofocusing (IEF) gels were run in a mini slab gel apparatus, in a
pH 3.5-10 ampholine gradient, according to the method of Robertson et al. (1987) and were stained with Coomassie blue according to the Bio-Rad IEF standards instruction sheet.

Western blotting. After electroblotting, unreacted sites on the nitrocellulose paper (NCP) were blocked with a $2 \%(w / v)$ solution of casein in $10 \mathrm{mM}$-Tris/ $\mathrm{HCl}, 0.9 \% \mathrm{NaCl}(\mathrm{pH} \mathrm{7.4)}$ (CTS) for $1 \mathrm{~h}$ at room temperature. The NCP was then incubated with an appropriate dilution of antiserum in the same buffer for $2 \mathrm{~h}$. The NCP was washed five times with Tris/saline (10 mm-Tris/ $/ \mathrm{Cl}, 0.9 \% \mathrm{NaCl}, \mathrm{pH} 7 \cdot 4)$. Then goat anti-rabbit immunoglobulin conjugated to alkaline phosphatase (Caltag Labs) was added in CTS buffer and incubated for $1 \mathrm{~h}$ at room temperature. After incubation, the NCP was washed five times in Tris/saline. The reactive bands were visualized as described by Blake $e t$ al. (1984) using 5-bromo-4-chloro-3-indolyl phosphate (Boehringer Mannheim) as the alkaline phosphatase substrate and nitroblue tetrazolium (Sigma) as the colour development reagent.

Amino acid composition. The purified protein was electroblotted on Immobilon transfer membrane (Millipore) following the method of Legendre \& Matsudaira (1988). The blotted protein was stained with Ponceau S (Sigma) following the method of Salinovich \& Montelaro (1986). The sample was subjected to gas-phase hydrolysis in $6 \mathrm{M}-\mathrm{HCl}$ for $1 \mathrm{~h}$ at $165^{\circ} \mathrm{C}$. Amino acid composition was determined on a $420 \mathrm{~A}$ derivatizer-analyser system (Applied Biosystems), using the standard program.

Immunoelectron microscopy. Bacteria were harvested, and washed once in 0.05 M-phosphate buffered saline (pH 7.2) (PBS). Single drops of bacterial suspension were placed on Formvar-coated grids and allowed to partially air-dry. The grids were then placed sequentially on drops of PBS containing $5 \%(\mathrm{w} / \mathrm{v})$ bovine serum albumin for $5 \mathrm{~min}$ and a suitable dilution of rabbit antiserum for $30 \mathrm{~min}$. They were then washed in distilled water and placed on drops of a $1: 10$ dilution of colloidal gold particles $(5 \mathrm{~nm})$ conjugated to goat anti-rabbit immunoglobulin G (E-Y Labs) for $30 \mathrm{~min}$. After a final wash in distilled water, they were stained with $2 \%(\mathrm{w} / \mathrm{v})$ phosphotungstic acid $(\mathrm{pH} 7 \cdot 0)$, and examined with a Philips 201 electron microscope at an accelerating voltage of $60 \mathrm{kV}$.

Haemagglutination test. This was done as previously described (Fortin \& Jacques, 1987). Rabbit blood was collected in Alsever's solution. The erythrocytes were washed twice in PBS and suspended in PBS to obtain a final concentration of $3 \%(\mathrm{v} / \mathrm{v})$. One drop of a bacterial suspension $\left(\sim 10^{10}\right.$ cells $)$ or purified fimbrin $(1 \mathrm{mg})$ was added to one drop of erythrocyte suspension in the circular depression of a glass slide. The slide was rocked, at room temperature, for $15 \mathrm{~min}$. In one experiment the bacterial suspension was incubated for $1 \mathrm{~h}$ with an equal volume of antiserum raised against fimbriae before doing the haemagglutination test.

\section{Results}

Electron microscopy using negative staining suggested the presence of short, flexible fimbriae on the cell surface of $R$. salmoninarum strains FMV 84-01 and ATCC $33209^{\mathrm{T}}$. These structures had an apparent diameter of less than $2 \mathrm{~nm}$, were most often seen in bundles, and were distributed peritrichously. Due to their small diameter, they were hard to observe unless labelled with antibodies and gold particles as described below. Our electron microscopic study did not reveal the presence of a protein surface array. 


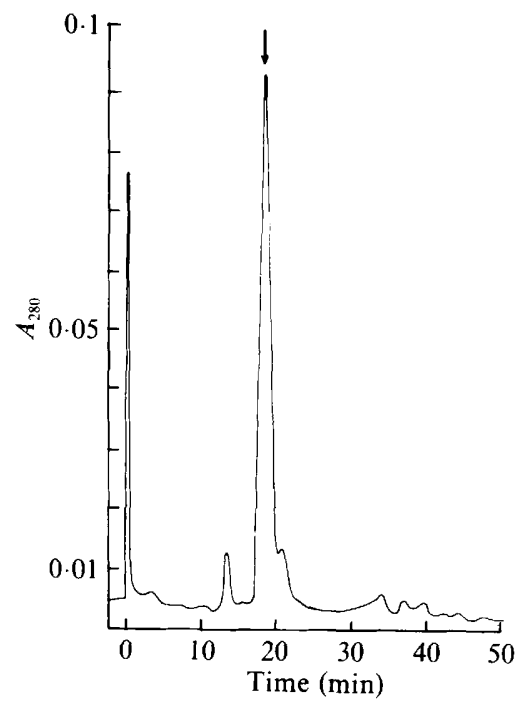

Fig. 1. FPLC elution profile of $R$. salmoninarum fimbrial protein using Superose 12 gel filtration column chromatography. The arrow indicates the elution peak containing the fimbrin.

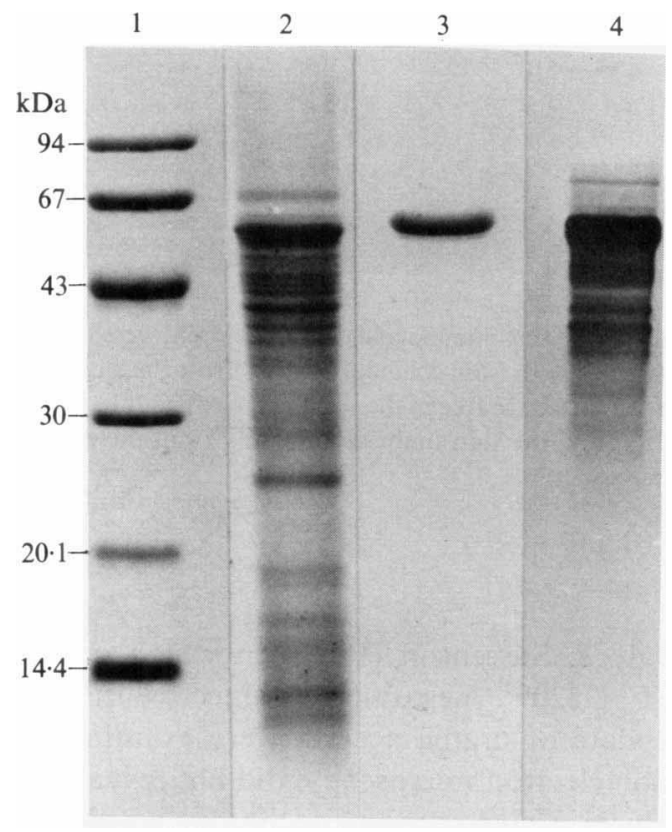

Fig. 2. SDS-PAGE and immunoblot of $R$. salmoninarum FMV 84-01. Lanes: 1, molecular mass markers; 2 , whole-cell lysate; 3 , purified fimbrial protein; 4 , immunoblot of whole-cell lysate using rabbit antiserum raised against homologous whole cells.

Fimbriae were isolated from cultures of strain FMV 84-01 as described in Methods, and purified to apparent homogeneity using an FPLC system coupled to a Superose 12 column. The fimbrin eluted after approximately $17 \mathrm{~min}$ in a single peak that represented the major component of the chromatographed sample (Fig. 1).
Table 1. Amino acid composition of the $57 \mathrm{kDa}$ surface protein from $R$. salmoninarum

\begin{tabular}{cc}
\hline \hline Amino acid & $\begin{array}{c}\text { No. of } \\
\text { residues } \text { mol }^{-1}\end{array}$ \\
\hline Asx & 83 \\
Thr & 47 \\
Ser & 38 \\
Glx & 36 \\
Pro & 28 \\
Aly & 107 \\
Val & 51 \\
Met & 54 \\
Ile & 0 \\
Leu & 12 \\
Tyr & 21 \\
Phe & 12 \\
His & 25 \\
Lys & 10 \\
Arg & 37 \\
Cys & 11 \\
Trp & ND \\
Total no. of residues mol & ND \\
Apparent mol. mass & 572 \\
Hydrophobic residues $(\%)^{*}$ & $57 \cdot 2 \mathrm{kDa}$ \\
\hline \hline
\end{tabular}

ND, Not determined.

* Val, Met, Ile, Leu, Ala, Phe, Trp and Pro.

SDS-PAGE of the material in this peak revealed a single $57 \mathrm{kDa}$ protein as assessed by Coomassie blue staining (Fig. 2, lane 3). Electrophoresis of the whole-cell preparation indicated the $57 \mathrm{kDa}$ protein band to be a major constituent of the cell (Fig. 2, lane 2). Schiff staining of the FPLC-purified protein gave a negative result (data not shown).

The analysis of amino acid composition revealed that the protein was rich in glycine $(18.7 \%$ of all residues), Asx (asparagine and aspartic acid), valine and alanine, whereas methionine was absent (Table 1). The molecule, comprising approximately 572 residues, was acidic, with Asx (asparagine and aspartic acid) and Glx (glutamine and glutamic acid) representing $20.8 \%$ of the residues, and $10.1 \%$ basic residues (lysine, histidine, arginine). It contained $33.4 \%$ hydrophobic residues. The isoelectric point was determined to be 4.8 under non-denaturing conditions.

Immunoblotting using serum raised against whole cells indicated that the $57 \mathrm{kDa}$ protein was surfaceexposed and constituted the immunodominant antigen (Fig. 2, lane 4). Using the rabbit antiserum raised against the purified protein and the immunogold technique we showed that the antibodies labelled the native fimbriae on strain FMV 84-01 (Fig. 3). This technique showed alignment of gold particles along some fimbriae. Broken fimbriae were labelled and appeared as aligned gold 

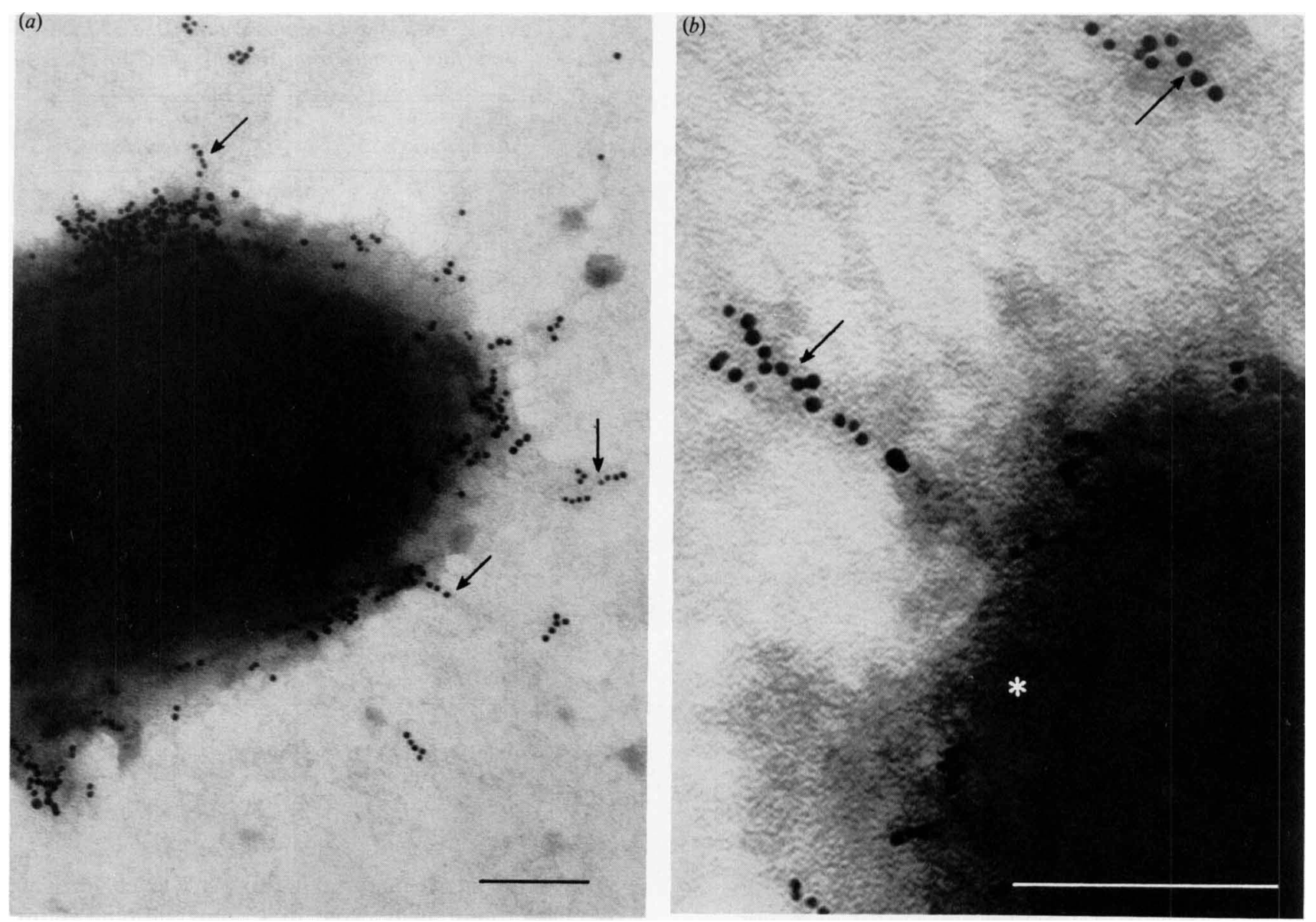

Fig. 3. Transmission electron micrographs of $R$. salmoninarum FMV 84-01 labelled by the immunogold technique. Cells were incubated with rabbit anti-57 kDa protein serum and then with goat anti-rabbit serum labelled with $5 \mathrm{~nm}$ colloidal gold. (a) Note the alignment of gold particles (arrows) suggesting the labelling of short fimbriae either on the cell surface or free in the surrounding medium. (b) Higher magnification of another preparation. Note the layer of capsular material (*) and the thin fimbriae radiating from the cell. Gold particles are seen along the length of some fimbriae (arrows). Bars, $100 \mathrm{~nm}$.

particles surrounding the cell. A capsular material layer of approximately $50-60 \mathrm{~nm}$ was also observed covering the cells.

Whole $R$. salmoninarum cells agglutinated rabbit erythrocytes. However, when the bacterial cells were treated with the antifimbrial antiserum, haemagglutination was inhibited. The purified $57 \mathrm{kDa}$ protein preparation could by itself agglutinate rabbit erythrocytes.

\section{Discussion}

Our study is the first report of the presence of fimbriae on the type strain, ATCC $33209^{\mathrm{T}}$, and one of our laboratory strains (FMV 84-01) of $R$. salmoninarum. The original description of $R$. salmoninarum did not include the presence of fimbriae (Sanders \& Fryer, 1986). The study of Daly \& Stevenson (1987), in which cells of strain ATCC $33209^{\mathrm{T}}$ negatively stained with ammonium molybdate or uranyl acetate were examined by transmission electron microscopy, did not reveal any surface structures. Using the same technique we observed short and flexible fimbriae, less than $2 \mathrm{~nm}$ in diameter. However, due to their small size their observation was rather difficult.

Removal of the fimbriae by washing the cells with distilled water suggests that they are easily broken. This hypothesis is likely as the material extracted with water was non-soluble (structured) and could be precipitated by low-speed centrifugation. PMSF was added as a protease inhibitor as Bruno \& Munro (1986) showed $R$. salmoninarum to produce different proteolytic activities. Omitting PMSF resulted in severe degradation of the fimbrial protein subunit. The protocol we 
designed resulted in purification to homogeneity of a single polypeptide with a subunit size of $57 \mathrm{kDa}$ by SDS-PAGE. Although this subunit size is higher than what is known for Escherichia coli or Salmonella, it is not unique. For example, the fimbriae of Actinomyces viscosus, another Gram-positive bacterium, are composed of $64 \mathrm{kDa}$ subunits (Masuda et al., 1981). The amino acid composition and isoelectric point were not markedly different from other fimbrins, with $33.4 \%$ hydrophobic residues and an acidic pI of $4 \cdot 8$. However, the hydrophobic amino acid residues in fimbrin of $E$. coli, for example, could represent as much as $50 \%$. In general, this high percentage of hydrophobic residues has been used in assigning hydrophobic properties to fimbriae (Isaacson, 1985). Sugars have been shown to be associated with different fimbriae, such as those of $E$. coli 987P (Isaacson \& Richter, 1981) and $N$. gonorrhoeae (Gubish et al., 1982). However, the purified $57 \mathrm{kDa}$ protein from $R$. salmoninarum was not stained by the Schiff method, suggesting that it is probably not a glycoconjugate.

Using immunoelectron microscopy, we have recently shown $R$. salmoninarum to be encapsulated (Dubreuil et $a l ., 1990$ ), and the present study confirmed the presence of a 50-60 nm thick capsule. However, the presence of this structure is not compatible with the demonstration of a hydrophobic cell surface by Daly \& Stevenson (1987), as the capsule is composed of polysaccharide. The presence of fimbriae radiating from the cell surface through the capsule could explain the hydrophobic nature of the cell surface. Fimbriae were seen projecting through the capsule $(50-60 \mathrm{~nm})$ and extending beyond it. However, the fimbriae were rather short. The length of $E$. coli fimbriae, for example, is variable but may be as much as $4 \mu \mathrm{m}$ (Ottow, 1975). However, we believe that the fimbriae of $R$. salmoninarum are longer but may be easily broken. Broken fimbriae, visualized as aligned gold particles, were present around the cells.

Immunoelectron microscopy showed antibodies binding along the length of the native fimbrial structures, confirming that the protein which had been purified was the fimbrial subunit and further showing that the epitopes recognized by the antibodies were surfaceexposed. Immunoblotting using whole-cell antiserum showed the $57 \mathrm{kDa}$ protein to be the immunodominant antigen on the surface of $R$. salmoninarum. Similarly, a study by Turaga et al. (1987) showed that the most prominent antigen found during the course of an $R$. salmoninarum infection had a molecular mass of approximately $60 \mathrm{kDa}$.

The fimbriae of $R$. salmoninarum may be an important virulence factor by increasing the hydrophobicity of the bacterial cells, which can be taken up more readily by macrophages, where they survive and are believed to replicate (Young \& Chapman, 1978; Bruno, 1986). Daly \& Stevenson (1987) showed that water-extracted haemagglutinin bound to phenyl-Sepharose and that the haemagglutinin was, at least in part, responsible for the hydrophobic character of the cell surface. Bacterial cells treated with heat or protease $K$, or from which the haemagglutinin had been extracted with water, demonstrated decreased hydrophobicity, indicating that a protein was probably responsible for the hydrophobicity and also that the hydrophobicity was associated with the haemagglutinating activity. Bruno (1988) showed that hydrophobicity and virulence in experimentally infected rainbow trout were linked. The presence of the $57 \mathrm{kDa}$ protein in saline extracts of virulent cells and its absence in extracts of avirulent cells suggested that it was contributing to, or associated with virulence (Bruno, 1990).

The ability of antifimbrial antiserum to inhibit haemagglutination, together with the ability of purified fimbriae to induce it, provide strong evidence that haemagglutination is mediated by the fimbriae of $R$. salmoninarum. Since the fimbriae are composed of the $57 \mathrm{kDa}$ protein previously shown to be the haemagglutinin, we speculate that the presence of fimbriae is probably a ubiquitous characteristic of virulent $R$. salmoninarum strains. To our knowledge, all virulent strains so far examined possess the $57 \mathrm{kDa}$ protein, are haemagglutinating and have a hydrophobic surface. Our study has demonstrated that fimbriae are present on the surface of two strains of $R$. salmoninarum, and that these appendages are responsible for the haemagglutinating activity. Further studies will focus on the elucidation of the role of these fimbriae in $R$. salmoninarum infections.

We thank Bernadette Foiry for her invaluable technical assistance and Charles M. Dozois for reviewing the manuscript.

\section{References}

Blake, M. S., Johnston, K. H., Russell-Jones, G. J. \& Gotschlich, E. C. (1984). A rapid, sensitive method for detection of alkaline phosphatase-conjugated anti-antibody on western blots. Analytical Biochemistry 136, 175-179.

BRUNO, D. W. (1986). Histopathology of bacterial kidney disease in laboratory infected rainbow trout, Salmo gairdneri Richardson, and Atlantic salmon, Salmo salar L., with reference to naturally infected fish. Journal of Fish Diseases 9, 523-537.

BRUNO, D. W. (1988). The relationship between auto-agglutination, cell surface hydrophobicity and virulence of the fish pathogen Renibacterium salmoninarum. FEMS Microbiology Letters 51, 135-140.

Bruno, D. W. (1990). Presence of a saline extractable protein associated with virulent strains of the fish pathogen, Renibacterium salmoninarum. Bulletin of the European Association of Fish Pathologists 10, 8-10. 
BRUNo, D. W. \& MUNRo, A. L. S. (1986). Uniformity in the biochemical properties of Renibacterium salmoninarum isolates obtained from several sources. FEMS Microbiology Letters 33, 247-250.

Bullock, G. L., Sutckey, H. M. \& Chen, P. K. (1974). Corynebacterial kidney disease of salmonids: growth and serological studies on the causative bacterium. Applied Microbiology 28, 811-814.

Daly, J. G. \& Stevenson, R. M. W. (1985). Charcoal agar, a new growth medium for the fish disease bacterium Renibacterium salmoninarum. Applied and Environmental Microbiology 50, 868-871.

Daly, J. G. \& Stevenson, R. M. W. (1987). Hydrophobic and haemagglutinating properties of Renibacterium salmoninarum. Journal of General Microbiology 133, 3575-3580.

Daly, J. G. \& SteVenson, R. M. W. (1989). Agglutination of salmonid spermatozoa by Renibacterium salmoninarum. Journal of Aquatic Animal Health 1, 163-164.

Daly, J. G. \& Stevenson, R. M. W. (1990). Characterization of the Renibacterium salmoninarum haemagglutinin. Journal of General Microbiology 136, 949-953.

Dubreuil, D., LALlier, R. \& JACQUeS, M. (1990). Immunoelectron microscopic demonstration that Renibacterium salmoninarum is encapsulated. FEMS Microbiology Letters 66, 313-316.

Fairbanks, G., Steck, T. L. \& Wallach, D. F. H. (1971). Electrophoretic analysis of the major polypeptides of the human erythrocyte membrane. Biochemistry 10, 2606-2617.

FIEDLER, F. \& DRAXL, R. (1986). Biochemical and immunochemical properties of the cell surface of Renibacterium salmoninarum. Journal of Bacteriology 168, 799-804.

FORTIN, M. \& JACQUES, M. (1987). Hemagglutination by Pasteurella multocida of porcine origin. Journal of Clinical Microbiology 25, 938-939.

FRYER, J. L. \& SANDERS, J. E. (1981). Bacterial kidney disease of salmonid fish. Annual Review of Microbiology 35, 273-298.

GeTCHell, R. G., Rohovec, J. S. \& Fryer, J. L. (1985). Comparison of Renibacterium salmoninarum isolates by antigenic analysis. Fish Pathology 20, 149-159.

Gubish, E. R., ChEN, K. D. S. \& Buchanan, T. M. (1982). Attachment of gonococcal lectin-resistant clones of Chinese hamster ovary cells. Infection and Immunity 37P, 189-194.

IsAaCsON, R. E. (1985). Pilus adhesins. In Bacterial Adhesion, pp. 307-336. Edited by D. C. Savage \& M. Fletcher. New York: Plenum.
ISAACSON, R. E. \& RichteR, P. (1981). Escherichia coli pilus: purification and partial characterisation. Journal of Bacteriology 146, 784-789.

Kusser, W. \& Fiedler, F. (1983). Murein type and polysaccharide composition of cell walls from Renibacterium salmoninarum. FEMS Microbiology Letters 20, 391-394.

LAEMMLI, U. K. (1970). Cleavage of structural proteins during the assembly of the head of bacteriophage T4. Nature, London 227, 680-685.

LEGENDRE, N. \& Matsudaira, P. (1988). Direct protein microsequencing from Immobilon-P transfer membrane. Biotechniques 6, 154-159.

Masuda, N., Ellen, R. P. \& Grove, D. A. (1981). Purification and characterisation of surface fibrils from taxonomically typical Actinomyces viscosus WVU627. Journal of Bacteriology 147, 1095-1104.

Oттоw, J. C. G. (1975). Ecology, physiology and genetics of fimbriae and pili. Annual Review of Microbiology 29, 79-108.

Robertson, E. F., Dannelly, H. K., Malloy, P. J. \& Reeves, H. C. (1987). Rapid isoelectrofocusing in a vertical polyacrylamide minigel system. Analytical Biochemistry 167, 290-294.

Salinovich, O. \& Montelaro, R. (1986). Reversible staining and peptide mapping of proteins transferred to nitrocellulose after separation by sodium dodecylsulfate polyacrylamide gel electrophoresis. Analytical Biochemistry 156, 341-347.

SANDERS, J. E. \& FR YER, J. L. (1986). Genus Renibacterium Sanders and Fryer, 1980, 501. In Bergey's Manual of Systematic Bacteriology, vol. 2, pp. 1253-1254. Edited by P. H. A. Sneath, N. S. Mair, M. E. Sharpe \& J. G. Holt. Baltimore: Williams \& Wilkins.

SMITH, I. W. (1964). The occurrence and pathology of Dee disease. Freshwater Salmon Research 34, 1-12.

TowBin, H., Staehelin, T. \& GordON, J. (1979). Electrophoretic transfer of proteins from polyacrylamide gels to nitrocellulose sheets: procedure and some applications. Proceedings of the National Academy of Sciences of the United States of America 76, 4350-4354.

TURaGa, P. S. D., Weins, G. D. \& KaAtTaRI, S. L. (1987). Analysis of Renibacterium salmoninarum antigen production in situ. Fish Pathology 22, 209-214.

Young, C. L. \& CHAPMAN, G. B. (1978). Ultrastructural aspects of the causative agent and renal histopathology of bacterial kidney disease in brook trout (Salvelinus fontinalis). Journal of the Fisheries Research Board of Canada 35, 1234-1248. 